Başvuru Tarihi: 22.10.2017 Received Date: 22.10.2017

Yayına Kabul Tarihi: 03.01.2018 Accepted Date: 03.01.2018

Yayınlanma Tarihi: 29.01.2018 Published Date: 29.01.2018
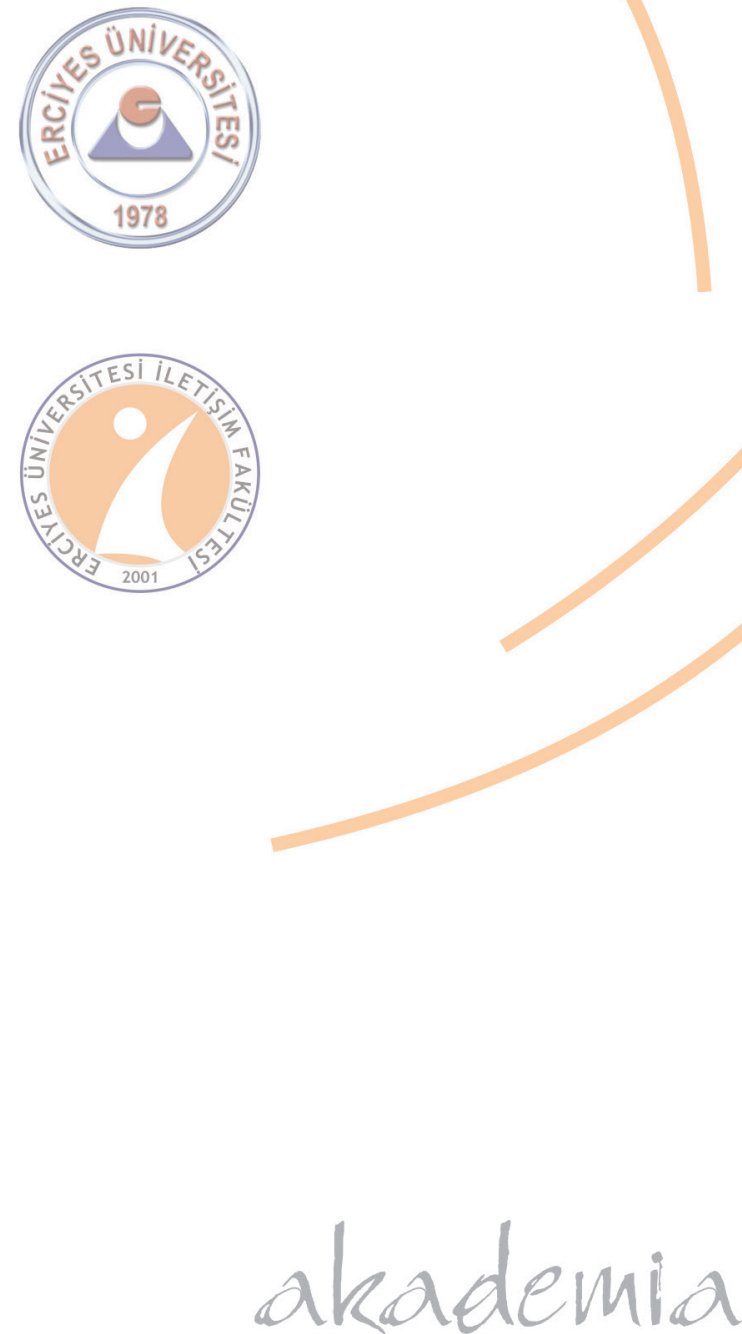
ISSN:1308-3198

Erciyes İletişim Dergisi akademia 2018

Cilt (Volume): 5, Sayı (Number): 3, (124-140)
Kenan DEMIR (Yrd. Doç. Dr.)

İstanbul Medipol Üniversitesi

İşletme ve Yönetim Bilimleri Fakültesi

kdemir@medipol.edu.tr

\section{OSMANLI BASININDA SA'Y U AMEL TARTIŞMALARI}

\section{$\ddot{O}_{z}$}

Teşebbüs-i şahsi fikrini savunan Osmanlı aydınları 19. yüzyılda Osmanlı devletinin iktisadi olarak Batı devletleri karşısında geri kalmaların farkına vardıklarından Batı'daki gelişmeleri takip etmeye başlamışlar ve Avrupa devletlerinin iktisadi olarak gelişmesinin arkasındaki ana nedenleri tespit etmeye koyulmuşlardır. Aydınlar, Batı'da halkın teşebbüs-i şahsi fikriyle hareket ederek özel girişim faaliyetlerinde sa'y u amel ettiklerini ve çalışma psikolojisinin ekonominin tüm sektörlerinde önemli bir rol oynadığını gözlemlemişlerdir. Bu nedenle sa'y u amel düşüncesini Osmanlı halkına aşılamak için çabalamışlardır. Bu doğrultuda halkın sa'y u amel etmesiyle ülkedeki ekonomik sıkıntıların ortadan kalkacağını ve üretimin artacağını ifade etmişlerdir. Aydınlar halka ulaşmak ve onları eğitmek amacıyla gazetelerden faydalanmışlar, dönemin gazetelerinde halkı bilgilendirmek ve onlara modern fikirleri aşılamak amacıyla birçok yazı kaleme almışlardır. Bu çalışmanın konusu olan sa'y u amel üzerine de aydınlar dönemin basınında birçok yazı kaleme almışlardır. Bu yazılarla halkın çalışmaya olan rağbeti artırılmak istenmiş ve halkın teşebbüs-i şahsi fikri doğrultusunda çalışmaları gerektiği ifade edilmiştir. Ayrıca halkın maddi sa'y olarak çalışmasının yanında onların akli sa'ya da önem vermelerini ve bugünkü modern teknolojilerin akli sa'y sonucu oluşturulduğunu dile getirmişlerdir. Osmanlı devletinin kalkınması ve ülkede teknolojinin gelişmesi için halkın akli sa'yini kuvvetlendirmesini istemişlerdir. Bu çalışmada Osmanlı basınında görülen sa’y u amel yazıları tespit edilmiş, çıkan yazıların analizi yapılmıştır.

Anahtar Kelimeler: Osmanlı Devleti’nde Basın, Sa’y, Çalışma, Ekonomi.

\section{DISCUSSIONS ON SA'Y U AMEL IN THE OTTOMAN PRESS}

\section{Abstract}

The Ottoman intellectuals began to follow developments in the West as they recognized that the Ottoman state in the 19th century has fallen economically against Western states and they are proceeded to identify the main reasons behind the economic development of European states. Intellectuals observed that in the West the people conducted in private enterprise activities by acting on the idea of personal enterprise and working psychology played an important role in all sectors of economy. For this reason, they tried to overcome the idea of private enterprise to Ottoman people. In this direction, they thought that the economic troubles in the country would be removed and production will increase from the standpoint of the people turning to private enterprise. The intellectuals benefited from the newspapers to reach out to the public and to educate them and for this reason they received many articles in order to inform the people in the periodicals and to give them modern ideas. The intellectuals have received many articles in the press of the period on the subject of this study. With these letters, it is desired to increase the interest of the people to entrepreneurship and it has been stated that the people should work in the direction of the private enterprise. It has also been expressed that people should give importance to scientific studies besides economic effort and also mentioned that today's modern technologies are the result of these studies. They also wanted to strengthen the scientific accumulation of the people for the development of the Ottoman state and the improvement of technology in the country. In this study, the articles of private enterprise seen in the Ottoman Press were determined and the content analysis of the published works was made.

Keywords: Press in the Ottoman Empire, Enterprise, Work, Economy. 


\section{Giriş}

Osmanlı aydını, 19. yüzyılın ilk yıllarından itibaren Batı karşısında gerilediğinin farkına varmış, bu doğrultuda Batı dünyasını gözlemlemeye başlamıştır. Batı dünyasının ekonomide gösterdiği başarının nedeni olarak teşebbüs-i şahsi doğrultusunda sa'y u amel etmelerine bağlamışlardır. Batı'da devlet görevlisi olarak bulunan yâda eğitim amacıyla giden Osmanlı aydını Osmanlı devletinin iktisadi olarak gerilemesinin ana nedenini çalışma zevkinin fazla olmamasına bağlamışlardır. Aydınlar, halktaki sa'y u amel eksikliğini halkın, günlük ihtiyaçlarını temin edecek kadar kazandıktan sonra fazla kazanç peşinde koşmamaları ve özel teşebbüs getiren işlerden çok memur olma hevesinde olmaları gibi nedenlerle açıklamışlardır. Halkın ticaret ve sanayi gibi sektörlerde girişimlerin eksik olduğunun farkında olan aydınlar halkta bu sektörlerde çalıșma dürtüsü uyandırmak amacıyla gazeteleri kullanmıșlar ve gazetelerde çalıșma üzerine birçok yazı yazmışlardır.

1831 senesinde Takvim-i Vekayi'nin yayımlanmasıyla Osmanlı'da ilk defa görülen gazeteler ilk yıllarda fazlaca etkili olamamış, ancak 1860'tan itibaren ülkede halkı aydınlatma ve bilgilendirme görevlerini icra etmeye başlamıştır. Dönemin gazeteleri devletin iktisadi sorunları hakkında görüşler öne sürmüş ve halkın devletin politikalarından haberdar olması doğrultusunda bir yayım politikası izlemiştir. Gazeteler, halkın eğitimini artırmak amacı doğrultusunda çalışmış, halkın bilgi seviyesini ve dünya görüşünü oluşturmak amacıyla aydınlatıcı yazılar da yayımlamıştır.

Aydınlar, Osmanlı devletinin iktisadi olarak gerilemesinin nedenlerini dönemin basınında tartışmışlar ve çeşitli öneriler sunmuşlardır. Aydınlar, Batı'nın kalkınmasını teşebbüs-i şahsi fikrinin burada yaygın olmasına bağladıklarından Osmanlı'da bu düşüncenin yaygınlaşması için yazılar kaleme almışlardır. Aydınlar, yazılarıyla halkın geçimini karşılaması için çalışma dürtüsünü fazlalaştırmaya çalışmışlar ve onların devlet kapısında çalışmalarından ziyade özel teşebbüs gerektiren işlerde sa'y u amel etmelerini istemişlerdir. Halkın çalışma dürtüsünü artıran ve çalışmayı öven yazılar kaleme almışlar bu doğrultuda halka çalışma psikolojisi aşılanmak istenmiştir. Maddi sa'yın yanında akli sa'yın öneminden de bahsetmişler ve akli sa'yın çalışmada çok önemli bir güç olduğunu vurgulayıp ve halkı bu noktada aydınlatmaya çalışmışlardır.

$\mathrm{Bu}$ çalışmada 1860 senesinden sonra gerçek anlamda kamuoyu olușturan gazetelerde yayımlanan sa'y u amel vurgusu tespit edilmeye çalışılmıştır. Çalışmada öncelikle dönemin kamuoyunu şekillendiren basının doğuşu ve gelişimi anlatılmış sonra dönemin basınındaki sa'y $\mathrm{u}$ amel yazıları tespit edilerek bu yazıların analizi yapılmıştır.

\section{Sa'y u Amel Yazıların Görüldüğü Gazetelerin Künye Bilgileri}

Osmanlı'da ilk gazetenin yayımlanmasından sonra diğer gazete örneklerinin görülmesinin yavaş olmasına karșın 1860'lı yıllardan itibaren gazetelerin sayısı artmış ve içeriği de zenginleşmiştir. Bu bölümde öncelikle ilk yayımlanan gazeteler belirtildikten sonra sa'y u amel yazıların çıktığı gazeteler hakkında kısaca bilgi verilecektir.

Osmanlı'da ilk gazete olan Takvim-i Vekayi 1831 senesinde hükümet tarafindan yayımlanmış, ama gazete halk tarafindan pek rağbet görmemişti (Karpat 2005, 218-220). Takvim-i Vekayi, devletin resmi gazetesi olarak içerde etkin olmaya çalışmış, ancak gerek baskı sayısı gerekse düzenli çıkmadığı için etkisi sınırlı kalmıştır (Ortaylı 2000, 197) 1840'da yayımlanan ve yarı resmi gazete olarak bilinen Ceride-i Havadis İngiliz tüccar William Churchill tarafindan çıkarılmıştır (Berkes 2003, 261). Ceride-i Havadis, gerek dış görünüşü gerek içeriği yönünden Takvim-i Vekayi benzemektedir. Gazete ticari bir zihniyetle yönetilmiştir. İlk yıllarda pek rağbet görmemesine karşın Kırım savaşı yıllarında büyük bir ilgiyle karşılaşmış ve sütunlarda da zengin içerikler yer almaya başlamıştır. Savaş yıllarında cepheden haberler veren ek ilaveler yayımlamıştır (Yazıcı 1994, 66). 1860 senesinde Agah Efendi ve Şinasi tarafından yayımlanan Tercüman-ı Ahval gazetesiyle Osmanlı'da basın gerçek anlamda kamuoyu oluşturmaya ve siyasal eleştiri görevine başlamıştır. Gazete sadece siyasi olaylarda değil; dil ve edebiyatta da yenilikler önermiş ve tartışmalar yürütmüştür (Ortaylı 2000, 198). Tasvir-i Efkâr 1862 senesinde 
Şinasi yönetiminde çıkmıştır. Tasvir-i Efkâr bir siyasi gazete olmaktan ziyade dönemin önemli gazetecilerin yetiştiği bir mektep vazifesini yürütmüştür (Ziyad 2007, 206-212).

Dönemin önemli bir kültür ocağ1 olan Cemiyet-i İlmiyye-i Osmaniye'nin yayın organı olarak çıkan Mecmua-i Fünun 1862 senesinde yayımlanmıştır. Мecmua-i Fünun, Batı düşüncesinin ülkede yayılması için Batı düşüncesi kavram ve sistemlerini ülkede yayma görevini benimsemiş, yayın politikasını bu doğrultuda sürdürmüştür (Mardin 2002, 267). Dergi birkaç kesintiye rağmen 1867 senesine kadar 47 sayı çıkmış, fizik, kimya, biyoloji, tarihi, dil, pedegoji, mantık, ekonomi ve felsefe gibi hemen hemen tüm bilimlerde Batı düşünce ve kültürünü Osmanlı okuyucusuna öğretmeyi hedeflemiştir. 18. asırda Fransa'da ansiklopedistlerin oynadıkları rolü Osmanlı'da bu dergi yürütmüştür (Uçman 1999, 12). Мecmua-i Fünun'da iktisadi yazılar genişçe yer almıştır. İktisadi yazıların önemli bir kısmı Münif Paşa tarafından yazılmıştır. "İlga-yı Kavaim-i Nakdiye" başlıklı makaleyle Osmanlı'da kâğıt paranın tarihi hakkında bilgi verilmiş, "Tarih-i Evrak-1 Nakdiyye-i Ber-Vechi-i Umumi” başlıklı makalede ise para konusu işlenmiş ve bir merkez bankası olma zorunluluğuna değinilmiştir (Budak 2004, 247). 1866 senesinde Filip Efendi'nin sahibi olduğu ve Ali Suavi'nin başyazarlığını yaptığı Muhbir gazetesi çıkmıştır (Çavdar 2014, 103). Muhbir'in üzerinde en fazla durduğu konu Babıali'nin dış politikasıydı. Girit sorununa yönelik cılız ve etkisiz siyaseti eleştiren Muhbir sütunlarında çok sert tenkit yazıları yayımlamıştır. Gazete, Girit'e yardım kampanyası düzenlemiş ve kamuoyunu yönlendirmiştir. Muhbir halk tarafindan gelen mektupları da yayımlamıştır. Bununla Muhbir, halkın konuşma fırsatı yakaladığı bir platform haline gelmiştir. Muhbir'in yayım politikasından rahatsız olan Babıali gazeteyi kapattırmış ve Ali Suavi'yi Kastamonu'ya sürgüne göndermiştir (Çavdar, 2007, 29). 1873 senesinde Ebuzziya Tevfik tarafından yayımlanan Cüzdan dergisi ilk sayısında kapatılmış, hükümet memurları gazetenin nüshasını toplamak için matbaaya geldiklerinde 1.500 nüshasının sadece 200 sayısına el koyabilmişlerdi (E. Tevfik 1973, 431). Küçük boy, resimsiz ve 30 sayfa çıkan Cüzdan, ilk sayısında yayım politikasını halkın toplumsal, kültürel ve siyasi konularda bilgilendirilmesini ve eğitimi sağlamak olarak açıklamıştır (Nalcıŏlu 2013, 311).

1883 senesinde A. Kamil tarafından Afak dergisi çıkmıştır. Dergi, dönemin ruhuna uygun olarak siyasetten başka her şeyden bahseder düsturuyla hareket etmiş, dergide edebiyat, bilim ve ekonomi yazıları genişçe yer almıştır (Şen 2009, 384). Dergide, şiir, matematik ve tıp üzerine yazılar da görülmüştür (Varlık 1985, 115). Fenelon, Lamartine ve Musset gibi Batı düşüncesine mensup kişilerin eserleri tercüme edilerek yayımlanmıştır (Özlük 2011, 203). Derginin çıkmasında Muallim Naci'nin önemli katkıları olmuş, her sayıda şiir, nesir ve tenkit yazıları yer almıştır (Okay 1988, 396). 1883 senesinde Beşir Fuat öncülüğünde yayımlan Güneş, dönemin önemli bir düşünce dergisidir (Güneş 1986, 409). Derginin her sayısında Şemsettin Sami'nin ilim ve fen, Mustafa Azmi'nin ekonomi bilimi, Besim Ömer'in sağl1k hakkında yazıları yer almıştır (Okay 1996, 296). Abdülhak Hamid, Ahmet Rasim, Hüseyin Avni, Muallim Naci ve Şemsettin Sami gibi dönemin önemli yazarların görüldügü Güneş, altı ay yayımını sürdürebilmiştir (Varlık 1985, 115). Gayret, 1886 senesinde haftalık olarak Menemenlizade Tahir tarafindan yayımlanan edebiyat dergisidir (Gayret 1986, 293). Gayret, farkındalık yaratmak amacıyla farklı sayılarda dönemin önemli edebiyatçıların mektuplarına yer vermiş ve mektuplaşmalar şeklinde edebi tartışmalar dergide fazlaca görülmüştür (Varlık 1985, 115). Maarif, siyasetten başka her şeyden bahseder yayın politikasıyla Kaspar tarafından 1891 senesinde yayımlanmıştır (Okay 2003, 272). Maarif, yeni çıkan kitaplar hakkında sütunlarında tanıtıcı bilgiler vermiştir. Ayrıca, sütunlarda edebiyata geniş bir ayırmış, yerli ve yabancı eserlerden birçok tefrikalar yayımlamıştır (Maarif 1986, 108). Maarif, 1892 senesinde Ramazan ayı münasebetiyle özel sayılar yayımlamış, bu sayılarda ramazan ayının önemi, oruç, teravi, sadaka ve kadir gecesi gibi dini konular hakkında çeşitli yazılar ağırlıkla yer almıştır (Yazıc1 2003, 51-52). Mütalaa, 1897 senesinde yayımlanmış ve dergi edebiyatta yenilik taraftarı olmuş ve Osmanlılık görüşü doğrultusunda yayım politikasını izlemiştir (Mütalaa 1986, 486). 


\section{Gazetelerde Çıkan Sa'y u Amel Yazıların İncelenmesi}

Osmanlı devleti 19. yüzyılın ilk başlarında iktisadi olarak Avrupa devletleri karşısında geri olduğunun farkına vardıktan sonra bu açığı kapatmak amacıyla birçok iktisadi teşebbüste bulunmuştur. Devlet, ülkede yerli üretimin azalmasını engellemek amacıyla birçok fabrika kurma teşebbüsüne girişmiş ve ülkede birçok fabrikalar kurmuştur. Bu teşebbüsün başarısız olmasından dolayı ülkede halkın teşebbüs-i şahsi gerektiren işlere olan rağbeti artırılması amacıyla dönemin basınında birçok yazı görülmüş ve devlet de özel teşebbüsü teşvik eden birçok politika uygulamıştır. Ülkede halkın sanayi ve ticaret gibi sektörlerde rağbet etmemesinin nedeni bu meslekleri küçümsemesi olarak görülmesi nedeniyle gazetelerde bu meslekler lehine kamuoyu oluşturulmak amaçlanmıştır. Dönemin terminolojisi ile sa'y u amel vurgusu 1860 'lı senelerden 1890'lara kadar hemen hemen tüm aydınlar tarafından dillendirilmiş, halka yönelik teşvik edici yazılar yazılmıştır. Osmanlı'nın iktisadi geri kalmasının nedeni olarak halkın özel teşebbüs tarzlı işlerde çalışmaması gösterilmiştir. Osmanlı gazetelerinin uzun soluklu olmaması ve gazetelerin ansiklopedist bilgi vermesi nedeniyle çalışma hakkında yayımlanan yazılar fazla olmamaktadır. Bu çalışmada dönemin basınında görülen tüm çalışma yazıları incelenmiştir. Sa'y u amel hakkında ilk yazı Mecmua-i Fünun da yayımlanmıştır.

Мecmua-i Fünun'da Ohannes Efendi tarafindan yazılan "İlm-i Servet-i Milel” başlıklı makalede çalışmanın her türlü servetin kazanılmasında önemli rol oynadığ İnsanoğlunun yiyecek, giyecek ve barınma gibi tüm ihtiyaçlarının çalışarak elde ettiği ifade edilmiştir. Çalışma sonucu ülkelerin terakki ettiği ve teknolojin sa'y u gayretin sonucu olduğu belirtilmiştir. Ülke kalkınmasının insanoğlunun çalışması sonucu elde edildiği ve servet sahibi olmanın en önemli şartının aklen ve madden sa'y u amel olduğu ifade edilmiştir. Toplumdaki ihtiyaçların sa'y u amel sonucu ortadan kalktığı ve ülkelerin ulum ve sanayide ilerlemesinin çalışmanın sonucu olduğu bildirilmiştir (Ohannes Efendi 1862, 86-88).

Mecmua-i Fünun'da yayımlanan diğer bir yazı olan "Lüzum-1 Sa'y u Amel” başlıklı makalede Şerif Efendi, çalışmanın öneminden bahseder. İnsanoğlunun dünyaya gelip ebeveynlerin koruyuculuğundan çıktıktan sonra ihtiyaçlarını karşılaması için çalışmasının bir gereklilik olduğunu vurgular. Sonra manevi sermaye olarak ifade ettiği “nukud-i maneviye'nin insanın tasarruf ettiği tüm ürünlerin karşılığı olduğunu ve tüm mal ve hizmetlerin sa'y u amel sonucu elde edildiğini belirtir. Parayı ise çalışma sonucu elde edilen sermaye olarak görür, bir kişinin servetinin emek sarfiyla elde edildiğini ifade eder (Şerif Efendi 1863, 333-334). İnsanoğlunun gerek zorunlu gerekse zorun olmayan tüm gereksinimlerin çalışmayla elde ettiğini vurgular. Şerif Efendi'ye göre; "İmdi gerek havayic-i zaruriye ve gerek gayr-i zaruriyemizin istihsali emrinde nev-i beni ademe lazım olan (sa'y u amel) olup yoksa ömr ü zeydin vehm ü kıyas ettikleri meskukatı cariye değildir. Çünkü meskukat-ı mücerred sa'y u amel mukabilinde kazanılmış bir sermaye olduğundan harç olunup bittikte başkasının tahsili mutlaka sa'y u amele muhtaç olduğu ve binanaleyh efrad-ı beşerin sa'y u amelsiz refah ü asayiş-i hal istihsali mümkün olmayacağı kazaya-yı müsellemedendir." (Şerif Efendi 1863, 334).

Şerif Efendi, insanoğlunun sa'y u amelinden fazla verim elde edebilmesi için çalışma eylemini ak1l ve hikmete uygun olarak icra etmesini ve hem maddi hem de akli kuvvetini çağın şartlarına göre güçlendirilmesini ister. Bir kayıkçının bir saatçiden fazla kazanamamasını birincinin sadece maddi kuvvetiyle emeğini sarf ettiğini ama ikincisinin hem beden kuvvetini hem de beyin gücünü bir arada kullanarak sa'y u amel ettiğini ve bu doğrultuda fazla kazandığını belirtir (Şerif Efendi 1863, 334-335). İnsanoğlunun öğrendikleriyle yetinmemesini, yeniliklere açık olmalarını, ustalarından gördükleri gibi sanatlarını icra etmemelerini ve yüksek kazanç getiren işlerde asrın şartlarına göre uzmanlaşıp kendilerini geliştirmelerini ister, gerisini tevekkül ederek Allah'a havale etmeleri gerektiğini belirtir. Ustasından öğrendiği şekille zanaatını icra edip de kendisini geliştiremeyenlerin çok çalışsa bile yüksek bir kazanç elde edemeyeceğini ve topluma faydalı olamayacağını ifade eder (Şerif Efendi 1863, 335). 
Şerif Efendi, toplumun kalkınması için sa'y u amel ederek ticaretin yapılmasını ister ve ticaretteki kazancın toplumun yararına olduğunu ifade eder (Şerif Efendi 1863, 335). İnsanoğlunun sa'y u amelini helal yollara sevk etmesini ister ve bunu hamal-hırsı örneğiyle açıklar. Hamalın sa'y ederek çabaladığı bir yük naklinde elde edeceği ücretten hem kendisinin istifade edeceğini hem de yük sahibinin işinin görüleceğini ve bu doğrultuda iki tarafinda bundan istifade edeceğini belirtir. Ancak, hırsızın bir malı çalması için sarf ettiği emeğin sonucu elde ettiği yararın diğer kişinin zararına elde ettiği için bu kazancın haram olduğunu ifade eder, bu nedenle sa'y u ameli helal yollardan kazanılması gerektiğini dile getirir (Şerif Efendi 1863, 336).

Şerif Efendi, çalışma kudretinde olan bir kişinin çalışmayıp da başkalarına el açarak yaşamını sürdürmesini eleştirir, insanoğlunun çalışmakla mükellef olduğunu belirtir. İnsanoğlunun sa'y u amel ederek toplumun gelişmesi için çaba sarf etmesini ister. Bilgi ve donanımını geliştirmesiyle hem kendisine hem de topluma hizmet etmesi gerektiğini belirtir (Şerif Efendi 1863, 336). İnsanoğlunun sa'y u amelle gerçekleştirdiği bazı üretimlerin toplum için zaruri olmasa bile icat edilmelerinin medeniyet açısından yararlı olduğunu ifade eder. İnsanoğlunun sa'y u amelini icra ederken toplumla olan mübadelesinde bazen zararlı teşebbüslerin olacağını belirtir. İnsanoğlunun bu durumu ortadan kaldırmak için sağduyulu bir şekilde girişimlerde bulunmasına karşın bunu başaramayacaklarını, gerçek çözümün manevi kuvvetin terbiyesiyle gerçekleştireceklerini ifade eder (Şerif Efendi 1863, 336-337).

Ülkede sa’y u amel düşüncesinin yaygınlaşması için çaba harcayan Mecmua-i Fünun, sayfalarında Batı düşüncesinden örnekler verdiği gibi çalışma psikolojisinin İslam düşüncesinde de olduğunu vurgulayan yazılar da yayımlamıştır. Bu doğrultuda Мeстиa-i Fünun'da yayımlanan "Medh-i Sa'y ve Zemm-i Betalet Hakkında Meşahr-i Ulema-yı İslamiyeden Kemal Paşazadenin Arabi Risalesinin Tercümesidir" başlıklı yazıda Pertev Paşa, Kemal Paşazade'nin eserini tercüme ederek Kemal Paşazade'nin çalışma hakkındaki görüşlerini okurlara aktarır. Risalenin amacının çalışmayı övmek tembelliğin ise kötülemek olarak açıklar. Makalede, Necm süresi 39. ayette insanların ancak çalıştıkları ile var olduğu belirtilmiş, insan rızkının çalışma sonucu elde edildiğini ve ticareti de helal kıldığı ifade edilmiştir (E. Pertev, 1865, 281). İnsanın rızkını ancak talep edip çalışarak elde ettiği ve insanoğlunun çalışmayla rızkını kazandığ 1 vurgulanmıştır. İnsan rızkını ancak sa'y ile toplayacağını ve bu yolda mücadele etmesinin dinen de teşvik edildiği ifade edilmiştir. Çalışmanın iyi ve tembelliğin kötü bir davranış olduğu belirtilmiş, Maide 2'de insanoğlunun iyilikte birbirine yardımlaşmasının ve Tevbe 71'de ise müminlerin birbirlerinin koruyucusu olduğu ve iyilik emretmesi, bu uğurda çalışmanın tavsiye edilmesi istenmiş ve tembellik üzerinde olanların kötülük içerisinde olduğu ifade edilmiştir (E. Pertev 1865, 282-283).

Risalede tembellik içerisinde olanları Allah'ın sevmediği ve miskin bir şekilde hayatlarını sürdürenlerin insanlık vasıflarından yoksun olduğu ifade edilmiştir. İnsanının hayatını devam ettirmesi için sa'y ile iştigal etmesi buyrulduğunu ve çalışma sonucu insanın maddi ve manevi menfaatlerini gözettiği belirtilmiştir. Bu doğrultuda insanoğlunun maddi ve manevi menfaatlerini korumak ve sürdürmek amaciyla sa'y u gayret etmesi istenmiştir. İnsanoğlunun sa’y u gayret ederek zenginleştiğini ama tembellik gösterilse toplumda zelil bir şekilde yaşayıp topluma yük olacakları ifade edilmiştir (E. Pertev 1865, 283).

Risalede insanın tembellik etmesiyle bunu içselleştireceği birçok organın görevini yapamaz duruma gelip bunun sonucunda işlevlerini yitireceğini ancak sa'y u gayret ederek insanoğlunun bundan istifade edeceği belirtilmiştir. İnsanoğlunun sa'y u gayret ederek nimetleri elde edeceği ve doğada var olan nimetleri çalışmak sonucu keşfederek menfaatine kullanacağını Meryem 25. ayeti kerime vurgulandığı gibi Hz. Meryem'in doğa da bulunan hurma ağaç dalına sa'y ederek ulaştığ 1 ve dalın kendi tarafına çekip nimetten istifade ettiği ifade edilmiştir (E. Pertev 1865, 284-285).

Risalede insanoğlunun rızkını kazanmak için çalışması gerektiği, çalışma sonucu elde edilen rızkın bazen meşakkatli olacağı, bunda sebat edilmesi gerektiği vurgulanmış ve Allah'ın bazı nimetleri uzun meşakkatler sonucu kuluna nasip eylediği belirtilmiştir (E. Pertev 1865, 285). Risalede tevekkül etmenin hiçbir şey yapmayarak oturmak olmadığı, dünyada kendisine 
taksim edilmiş rızkın peşinde koşmak ve bunun sonucu elde edilen rızka razı olmak olduğu ifade edilmiş ve insanoğlunu rızkını talep edip sa'y etmesi istenmiştir (E. Pertev 1865, 286).

Mecmua-i Fünun'da Macid Bey tarafindan yazılan "Lüzum-1 Sa'y u Amel” başlıklı makalede ise insanoğlunun çalışmadıkça yaşamayacağı vurgulanmıştır. Macid Bey, insanoğlunun maddi ve manevi ihtiyaçlarını karşılamak ve üretmek için sa'y u gayret etmesinin insan fitratının gerekliliği olduğunu ifade eder. İnsanoğlu sa'y u gayret ederek kendi ve çocuklarının rızkını karşılamak için mücadele ederken müşkülatlar içerisinde kaldığını belirtir. İnsanoğlunun sa’y u gayret ederek elde ettikleri kazanımları bir sonraki nesle bıraktıklarından yeni nesil hazır bulunan üretim araçları sayesinde sa'y u gayretlerinde kolaylıklar elde ettiklerini ve bu alet ve edevatları geliştirerek yeni aletler icat ettiklerini belirtir (Macid 1866, 201-202).

Macid Bey, insanoğlunun ihtiyaçların sadece zorunlu ihtiyaçlar olmadığını medeniyet ilerledikçe ihtiyaçların da o nispette arttığını, bu nedenle insanoğlunun kendi ihtiyaçlarının temininde sadece kendi sa'y u gayretin yetmediğini, bu doğrultuda toplumdaki diğer bireylerin yardımlarına muhtaç olduğunu belirtir. Toplumdaki bireylerin ihtiyaçlarını karşılamak için aralarında iş bölümüne gittiklerini sonra bunları mübadele ederek sa'y u gayretleri nispetinde hayatlarını sürdürdüklerini ifade eder. Paranın sadece mübadeleyi kolaylaştırıcı bir vasıta olduğunu, bu aracı ise insanların sa'y u gayretleri nispetinde elde ettiğini ve bu nedenle insanların mübadelelerinde tedavül eden asıl şeyin sa’y olduğunu belirtir (Macid 1866, 202).

Macit Bey, insanoğlunun sa'y ile mükellef olduğunu insanın sürekli çalışmanın imkânsız olduğunu söyler. Birtakım kişilerin sa'y u gayret etmeden yaşadıklarını ve tembellik ve avarelik ederek ömürlerin tüm ihtiyaçlarını karşıladıklarını belirtir. Bunların iki sınıf olduğunu belirten Macit Bey, birinci sınıfın eski derebeyleri gibi kendi cinsine hiçbir hizmet ve yardımda bulunmadan ahalinin servetini yağma ederek yaşayanlar ya da bu tarz bir servete miras konan kişilerin olduğunu belirtir (Macit 1866, 202-203). Derebeyleri gibi yaşayanlardan ziyade ikinci gruptaki kişiler hakkında konuşmaya başlar. İkinci gruptaki kişilerin ise zamanında kendi sa'yları sayesinde servet üretmiş, bir sürü emlaka malik olmuş kimselerin sa'y u gayretlerini terk ederek sonraları tembel bir şekilde sadece kendi refah ve rahatını düşünmeye başladıklarını ifade eder. $\mathrm{Bu}$ durumun hem kendilerinin hem de toplum için zararlı bir durum olduğunu bu nedenle servet sahibi olan kişilerin bu durumdan bir önce kurutulmaları gerektiğini belirtir. Her ne kadar büyük serveti sahibi olsalar bile elde olan servetin zamanla azalıp yok olacağından bu serveti uygun bir şekilde yönetmeleri gerektiğini söyler. Servetlerin artması için sa’y u ikdam etmeleri gerekirken çalışmayıp gevşeklik gösterdiklerini ve bu tarz servet sahibi olan kişilerin betalet içerisinde olmalarının toplum için büyük zarar olduğunu ifade eder. Bir toplumun tüm bireylerin doğrudan ya da dolaylı olarak istifade edeceği bu tarz bir servetin üretimde ve medeniyetin geliştirilmesinde kullanılmamasını tenkit eder. Bu tarz servetlerin toplumun kalkınması için üretim getirecek tarzda istifade edilmemesini hem eski birikimlerin heba olması açısından hem de bir sonraki neslin üretimin geliştirmesinde destek olunmaması açısından eleştirir. Mevcut sermayeyi sonraki nesillerin terakki yolunda ilerleme yaşaması ve zorluklar çekmemesi için şimdiki neslin biriken sermayeyi uygun şekilde istifade ederek çoğaltılması için sa'y u gayret etmeleri gerektiğini ifade eder. Mevcut sermayeyi betalet içinde tüketerek bitmesine çalışanları sert şekilde tenkit eder ve bu kişilerin eylemlerini insan cinayetine benzetir (Macid 1866, 203-205).

Macid Bey, servetin üretim için kullanmayıp da israf edenlerin neden toplumda saygın duyulduklarına şaşırır, bu tarz kişilerin servetlerini ilave bir fayda yaratmaları gerektiğini ifade eder. Şeriatın iyiliği emrettiğini, bunların servetlerin artırılması hususunda sonraki nesle iyilik etmediğini, kendilerine bahşedilen serveti sadece kendi zevk ve sefasına göre harcadıklarından toplumun kalkınmasında betalet içerinde olduklarını belirtir (Macit 1866, 205). Toplumda bazı kişilerin asilzadelik ve kibarlık kisvesine bürünerek boş oturmanın ulvi bir hareket olarak görerek tembellik içerisinde olduklarını tembelliği sa'y u ikdama tercih ettiklerini belirtir. Kibarzade takımın tüccar ve esnaf sınıfina hor baktıklarını ve evlatlarını bir zanaat sahibi olmaları ve ticaretle meşgul olmalarından ziyade onları devlet kapısında memur olmaları için çalıştıklarını aktarır (Macit 1866, 205-206). 
Dönemin önemli bir gazetesi olan Muhbir de çalışmanın önemine değinmiş, "Mukaddime" başlıklı giriş yazısında çalışmanın önemi anlatılmıştır. Yazıda, saadete ulaşmanın ve menfaat elde etmeyi sağlayanın medeniyet olduğu belirtilmiş ve medeniyet sonucu insanların sa'y u gayret ederek daha da geliştikleri ifade edilmiştir. Medeniyetin teşekkülünün sa'y u gayret sonucu elde edilen araç ve edevattan oluştuğunu ve insanoğlunu refaha ulaştırmanın yolu ise sa'y etmekten geçtiği belirtilmiştir. Saadete ulaşmak için bir şeyle meşgul olmak gerekir hadisi şerifi örnek verilerek sa’y u amel etmenin refaha ulaştıracağı dile getirilmiştir (Ali Suavi 1867, 1).

Ali Suavi, bir odaya vahşi adam konsa bu odayı güzelleştiremeyeceğini, başka bir şeye lüzum olmadığına kanaat getirdikten sonra sa'y u amel etmeyip tembel bir şekilde oturacağını ve çalışma olmadığı için menfaatten ve yarardan mahrum kalacağını belirtir. Bu odaya bir yörük konsa bu odayı güzelleştirmek için çaba harcayacağını ateş, kilim ve pencere gibi şeylerin lüzumuna kanaat getirerek bunları tedarik etmek için çalışıp çabalayacağını ifade eder. Bir köylü konsa bu oda için baca, kapı, sürgü, pencerelere kapak ve bildiği diğer şeyleri sa'y u amel ederek yapacağını söyler (Ali Suavi 1867, 1). Ali Suavi, ihtiyaçların karşılanması ve tedarik edilmesi için bu oda örneğinde olduğu gibi sa’y u gayret edilmesi gerektiğini ifade ettikten sonra şu sözleri söyler: "Kaldı ki medeniyetle lüzum bilip sa'y edenler işgali teksir edip yoruyorlar gibi görünüyorsa da emniyet ve rahat ve şeref ve ferah ve lezzet gibi menafi-i calib ve germ ü serd ve sarlk ve düssman gibi mazarrı dafi' olduklarından bunlar ehl-i sa'adet ve sa 'y etmeyenler bil'akis erbab-l şekavet demek olur. Zahir oldu ki, sa'adet sa'y ile olur. Levazım ne kadar çoğalırsa sa'y dahi o derece çok olmak lazım gelir" (Ali Suavi 1867, 1).

İktisadi sorunlara yazılarında genişçe yer ayıran dönemin en etkili yazarı Namık Kemal de sa'y'in iktisadi kalkınmadaki öneminin farkına varmış ve halkın özel girişim faaliyetlerinde sa'y etmemesini eleştirmiştir. Sa'y meselesinin genişçe ele alındığ 1 bir yazıyla halka çalışma psikolojini aşılamaya çalışmıştır. Cüzdan'da yayımlanan "Sa'y" makalesinde Namık Kemal, insanoğlunun sa'y sonucu elde ettiği kazancın mutedil bir şekilde harcaması gerektiğini anlatmıştır. Namık Kemal, "hiç ölmeyecekmiş gibi dünya için; yarın ölecekmiş gibi ahiret için çalış" hadisi şerifiyle İslam'ın her zaman iki dünya içinde çalışmasını istediğini belirtir. İnsanoğlunun dünyaya geldiğinde tüm ihtiyaçlarını karşılayacak bir ortam bulduğunu, bunu ise önceki insanların çalışma sonucu elde ettiği sa'y u gayretin neticesi olduğunu ve bu doğrultuda insanoğlunun kendinden sonraki nesle iyi imkânlar bırakması için sa'y içerisinde bulunması gerektiğini bildirir. Bunu önceki insanlara olan borcunun ödemesi olarak görür (Namık Kemal 1873, 2)

Namık Kemal, insanoğlunun fani olan bu dünyada sonsuza kadar yaşayacak gibi çalışması gerektiğini vurgular. İnsanoğlunun dünyadaki sa'yını sınırlayıp gevşeklik gösterirse sonunun fena olacağını belirtir (Namık Kemal 1873, 2). Birçok mirasyedi beyzadenin refah ve bolluk içerisinde yaşadığının görülebileceğini, bu gibilerin durumuna bakıldığında bahtiyar olmanın en önemli şartının dünyada beyzade gibi zengin bir ailede doğmak olduğunun anlaşıldığını ve buna dair hasretler çekildiğini aktarır. Bu gibilere gösterilen imrenmeyi sorgular ve beyzadeler gibi yaşamayı gıpta etmenin o kadar da imrenecek bir durum olmadığını belirtir. Hakikatin Allah'ın insanoğluna verdiği hassalar olduğunu; bahtiyarlığın ise bu hassaların iyi yollarda kullanımı olduğunu belirtir. Dünyadaki servetin ilki ketm-i ademden gelmemiştir diyerek tüm malların sa'y sonucu elde edildiğini şu sözlerle ifade eder: "Dünyada mal ttlak olunur ne var ise ikdam ile toplanır, sa'y ile vücuda gelir. Bu halden dolayı müzayakaya semere-i atalet, zarurete mahsul-i sefahat demek vardir. Ya bari sefahat ve ataletin bu meşakkatleriyle beraber arzuya değer bir zevki olsa." (Namık Kemal 1873, 2).

Namık Kemal, tembellik ederek sefahat hayatı yaşayan kişilerin bu dünyada en büyük sefalet sahibi kişiler olarak gösterir ve bu yolda olan kişilerin dünyada her türlü maddi sevinç içerisinde olacağını ama bundan ruhi bir sevinç duyamayacaklarını ifade eder. Tembelliği ölümün küçük kardeşi; safahatın yaşamın büyük düşmanı olarak görür, tembelliği yılana sefahati ise yılanda olan renkli ziynet eşyalarına benzetir. İnsanoğlunun bu tarz bir ortamda böyle bir ziynetle anılmasının bahtiyarlıkla bir ilişkisini olmadığını ifade eder. Namık Kemal'e göre, bu durumda olan bir tembel kişinin daha gençliğinden ihtiyarlar; çünkü işsiz geçen zamanın dakikası saatten 
daha uzundur. Zevk düşkünü biri dünyada ne kadar fazla yaşarsa bile ömrüne doyamadan gider, çünkü sefahat içerisinde geçen her vaktin saati dakikadan kısadır (Namık Kemal 1873, 2-3).

Namık Kemal, mirasyedi kişilerin dışarıdan bakıldığında eğlenceli ve huzurlu bir yaşamı görülmesine ve bu gibilerin eğlenceden eğlenceye koşmasına rağmen hayattan zevk alamadığını belirtir. Emek verilmeden elde edilen servetin tuzsuz yemeğe benzetir. İnsanın alın teriyle kazanmadığı parayla eğlenceden bile zevk alamayacağını bildirir. Kişinin kendi sa'yıyla kazandığı ile yaşaması gerektiğini, bu doğrultuda kazandığı takdirde zamanının kıymetini bileceğini ve eğlenceden de zevk alacağını belirtir (Namık Kemal 1873, 3). Sa'y sonucu servet elde eden kişinin ise eğlence peşinde koşmadığını; eğlenceyi kendi işinde aradığını bu doğrultuda iş peşinde koştuğunu söyler. Sa'yıyla servet edinenlerin vakitlerini boşa harcamadığını, vaktin değerli olduğunu bilerek zamanı değerlendirdiklerini ifade eder. Allah'ın kazananları sevdiğini bu nedenle insanın rahatı ancak sa'y u amel ederek kazanabileceğini belirtir (Namık Kemal 1873, 3).

Namık Kemal, insanoğlunun elbet bir gün öleceğini ama dünyaya ölmek için gelinmediğini, ayrıca insanın her türlü alçalmaya tahammül edebileceğini ancak bunun için yaratılmadığını ifade eder. İnsanoğluna çalışma yeteneğinin verildiğini, asli vazifesinin sa'y u amel etmek olduğunu söyler. İnsanın kısacık ömrümde yaşamak için sa'y u ikdam ile ömrünü geçirdiğini ve bu dünyaya nice eserler bıraktıklarını ifade eder. Ömrünü yiyip içmekle tüketenleri ve günübirlik yaşayıp geleceğini düşünmeyenleri eleştirir. Dünyada medeniyet namına ne varsa bunların yarını düşünenlerin eseri olduğunu ve günübirlik yaşayanların ise hiçbir eser bırakmadan mahvolup gittiklerini aktarır (Namık Kemal 1873, 3).

Namık Kemal, insanoğlu kazancını artırsa bile tasarruf etmesini ve kazancını kazanıyorum düsturuyla harcamamasını ister. Geleceğini garanti altına almanın iki kazanıp bir harcamakla elde edileceğini belirtir. Kazanmaktan çok harcamamanın önemli olduğunu vurgular, insanın çok para kazanabileceğini ama paranın geçen zamanı geri getirtemeyeceğini belirtir. Garip olanın insanının geleceğini düşünmeden tüm kazancını tüketmesi olduğunu belirtir. Namık Kemal, "zaman maye-i maişet, sa'y menba-ı hayattır. Adam zaman sayesinde gençleşir, sa'y ile yaşar. Bu halde zamanını sa'ye sarf etmeyip de muattal duranlar için toprağın altıyla üstünde ne fark olabilir?" der. Ülkede kalenderane bir itikat olan "her ne yaparsa Allah yapar, emekler, sa'yler hep beyhudedir" sözünü eleştirir. Her eyleminin failinin Allah'ın olduğunu ama sa'y etmeden hayattan el çekmekle Allah'ın kullarının hizmetkarı zannedilmesinin anlaşılabileceğini belirtir. Necm süresi 39 ayetini aktaran Namık Kemal "İnsan için çalıştığından başkası yoktur" ayetiyle çalışmanın önemini bir daha vurgular (Namık Kemal 1873,4). Kuran'da geçen yemek ziyafetinin bir mucize olarak geçtiğini ifade ederek insanoğlunun hayatını sürdürmesi için çalışması gerektiğini söyler. Sa’y sonucu elde edilen kazancın tümünün harcanmamasını ister ve bugüne kadar gelen eserlerin tasarruf edenlerin neticesi olduğunu söyler. Cimri kişileri eleştirenleri destekler ama sa'y u gayret etmeyip tembel olanları ve kazancını israf ederek harcayanların cimriden daha kötü davranışlar içerisinde olduğunu ifade eder (Namık Kemal 1873, 4).

Namık Kemal, kudreti olanların bu dünyada safa geçirmeleri gerektiğini ama neşelerinin devam edebilmesi için çalışmalarını ister. İnsanın harcamasına dikkat etmesi gerektiğini ve bugün aç yaşamasının yarınlarda birilerine muhtaç olmaktan daha iyi olduğunu bu doğrultuda harcamalarda mutedil olunmasını ister (Namık Kemal 1873, 4). İnsanoğlunun kazancını tasarruf ederek neslinin geleceğini garanti altına almasını ve onlara rahat ortamlar bırakması gerektiğini ifade eder. Bu sözlerin tembel olan kişiler için tesirli olamayacağını belirtir, onların ancak hayatın zorlukları ile karşılaşınca işin farkına varacaklarını söyler (Namık Kemal 1873, 4-5).

Yayımladığı ilk sayısı toplatılan ve kapatılan Cüzdan'da çalışma düşüncesi diğer yazılarda da görülmüştür. Ebuzziya Tevfik, Reşad Bey'in tercüme ettiği Franklin'in “Tarik-i Refah” adlı eseri neşredeceklerini belirtir ve çalışmanın öneminden kısaca bahseder. Tevfik Bey, kitapta yoksulluğun nedenin tembellik ve sefahat olduğunun vurgulandığını belirtir. Ecdadın sa'y ederek kazandıklarını bu neslin de maddi ve akli sa'yıyla çalışması gerektiğini ifade eder. Maddi çalışmadan ziyade akli çalışmanın önemli olduğunu, bugün tüm kazanımların fikirle elde 
edildiğini ve bu nedenle aklen çalışmaya fazla önem verilmesi gerektiğini belirtir. Halkın zanaat ederek geliştirdiği bir aletin ecdadın zamanında savaş meydanında gösterdiği başarılara eş değer olduğunu ve icat edilen yeni aletlerle devletin bundan büyük istifade elde edeceğini belirtir. İnsanın sa'y ile çalışması ile birlikte harcamanın da önemli olduğunu, kişilerin masraflarına dikkat etmesini ve israftan kaçınmasını ister (E. Tevfik 1873, 22)

Reşad Bey tarafından yapılan “Tarik-i Refah” adlı eserin tercümesinde Franklin çalışmanın öneminden bahsetmiştir. Franklin, tembelliğin rahatsızlık meydana getirip vücudu çürüttüğünü belirtir. İnsanoğlunun vakti israf etmemesi ve zamanın değerini bilinmesi gerektiğini söyler. İnsanoğlunun gayret ederek çalışması gerektiğini, çalışkanlık sayesinde çok şeyin üretildiğini ve işlerin kolaylaştığını ifade eder. Çalışkan kişinin erkenden kalkıp sa'y ettiğini, geç kalkanın ise işlerinin biriktiğini belirtir. Erken kalkan adamın zengin olacağını söyler. İnsanın çalışmada sebat etmesi gerektiğini, menfaatin zahmetsiz olmayacağını, meşakkatlerle mücadele edilmesini ister ve ikdam göstererek yılmadan çalışılması gerektiğini vurgular (Reşad Bey 1873, 22-23)

Franklin, zanaat sahibi olan insanların zaruretlerden korkmadığını bu kişilerin aç kalma ihtimalinin olmadığını ve bu kişilerin bolluk ve refah içerisinde yaşadıklarını belirtir. İnsanoğlunun bugünün işini yarına bırakmaması gerektiğini, kendi işinin başında olmasını ve işini takip etmesini ister (Reşad Bey 1873, 23). İnsanoğlunun işinde sabır ve metanet göstermesi gerektiğini, sürekli azar azar yapılan her işin üstesinden gelineceğini ve çalışırken sebat edilmesini ister. İnsanoğlunun istirahat etmesi gerektiğini ama bunun da çalışkan insanın hakkı olduğunu tembel insanını hiçbir zaman buna muvaffak olamayacağını söyler (Reşad Bey 1873, 24).

Franklin, sürekli iş değiştiren ve farklı mesleklerle iştigal eden kişilerin mesleklerinde başarılı olamayacağını bu nedenle insanoğlunun bir meslekte sebat ederek çalışmasını ister. İnsanoğlunun mesleğini severek icra etmesini ve işinde en ufak ayrıntıyı bile önemsemesi gerektiğini ve ufak bir eksikliğin büyük sıkıntılara sebep verebileceğini belirtir. Çalışmada başarılı olmanın bir diğer şartın itidal olduğunu ve dengeli bir şekilde sa'y edilmesini ister (Reşad Bey 1873, 24-25). İnsanoğlunun zengin olması için çalışması yanında kazandığı paranın idare edilmesinin de önemli olduğunu belirtir ve yapılan israfların sonucu insanın sa'yının boşa gideceğini söyler. İnsanoğlunun masraflarının gelirinden az olması gerektiğini ifade eder. Servetin sa'y ve tasarrufla elde edileceğini ve mirasyedilerin büyük servetlerinin israf ederek k1sa sürede bitirdiklerini bu nedenle harcamaya dikkat edilmesini ister (Reşad Bey 1873, 25-26).

1860-1876 dönemi basınında halkın özel girişim gerektiren teşebbüslerde bulunmasına yönelik teşvik edici yazılar yayımlandığı gibi II. Abdülhamit dönemi basınında da bu konu popülerliğini korumuş ve basında birçok yazı yayımlanmıştır. Dönemin edebiyat dergisi Afak sayfalarında bu konuya genişçe yer ayırmıştır. Afak dergisinde Mehmed Nadir tarafindan yazılan "Gayret-i Ciddiye" makalesinde çalışmada sürekliliğinin önemi anlatılmıştır. İnsanların toplumda birbirlerine hizmet için yaratıldıklarını belirten M. Nadir, bu hizmetin ise ancak gayret-i ciddiye ile gerçekleşeceğini vurgular. İnsanoğlunun çalışma gayretini sürekli diri tutmasını, sabah akşam demeksizin çalışmaya devam etmesini ister. İnsanoğlunun çalışma esnasında "benim elimden bu kadar gelir" sözü ile çalışmayı bırakmamalarını ister, tembellik edenlerin bu sözü sıklıkla kullandıklarını ve bunu bir düstur gibi kabullendiklerini ifade eder. Bugün medeniyette kalkınmış toplumların çalışma ve gayretlerin sürekliliği sonucu refaha erdiklerini söyler (M. Nadir 1882, 59).

Afak'da Fransız düşünür Tayr'ın “Çalışmak" başlıklı makalesi tercüme edilerek yayımlanmıştır. Makalede insanoğlunun dünyaya çalışmak için gönderildiği ve fitratının ana özelliğinin çalışmak olduğu belirtilmiştir. Tayr'a göre, bu dünyaya çıplak bir şekilde gönderilen insanoğlu tüm maişetini çalışmak sonucu elde etmeye mecburdur. İnsanın maişetini karşılamak için sa'y u gayretle mücadele etmesi gerekir. İnsanoğlu hayvanları toplayıp sürülerle beslemeye, onları avlamaya, ok yaparak hayvanları vurmaya ve avlanan eti ateşle pişirmeye, tabiattaki meyveleri ve ürünleri kendi zevkine uygun hale getirmesi için sa'y u gayret ederek terbiye etmeye, toprağ 1 işler hale getirmeye, yumuşatmaya ve kuvvetlendirmeye mecburdur. İnsanın sarf ettiği bunca 
sa'y u gayrete karşılık kazandığı şey hayatını idame ettirmesidir. İnsanoğlu yaşamını sürdürmesi hususunda gösterdiği çalışma azmiyle insanoğlunun yaşamındaki sefalet saadete, kaba post ipekli kumaşlara, kulübeler büyük konaklara ve saraylara dönüşmüştür (Tayr, 1882, 118-120).

Afak'da "Cümle-i Hikemiye" başlığ1 adı altında Batı düşünürlerinden güzel sözler verilmiştir. Bu güzel sözlerinin bazılarında çalışma övülmüş, tembellik ise yerilmiştir. Dergide verilen özdeyişlerden bazıları şunlardır: "Sa'y insanın hayatıdır." (Voltaire); "Tembellik bütün seyyiatın rehberidir" (Malebranche); "Seyyiâtın en büyüğ̈̈ tembelliği, bir istirahat add eylemektir, sihhat-i vücud şiddet-i zekâ ve istirahat-ı kalb sa'yin semerât-ı latifesindendir." (Vovnark); "Tembellerin aklı ve zekisi ne kadar parlak olursa olsun, yine adi adamlar sirasinda kalırlar." (Voltaire/Volter); "Cehaletin netayici vahimdir; tembellik onun birinci meyvesidir. Tembellik ise hatîanin menba'i olduğundan nihayet mahvdan başka bir netice hâsıl olmaz." (S. Orimon/Sent Orimon) (R. Tevfik, 1882, 7-9).

1883 senesinde ikinci yayım dönemine başlayan Мecmua-i Fünun ilk sayısında çalışma konusuna yeniden değinmiştir. Mecmua-i Fünun'da Münif Paşa tarafından yazılan “Tahsil-i Servet" başlıklı makalede insanoğlunun sa'y u amelde bulunarak yeni şeyler icat ettiği ve kıymeti olmayan malların kıymetlendirdiği ifade edilmiştir. Münif Paşa, sa'y u amelle bir maddeyi şekil vererek dönüştürdükten sonra faydalı bir alet haline getirildiğini belirtir. Servetin hammaddesi olan varlıkların doğada bulunduğunu, bu maddelerin üretimi ve çoğaltılmasının kolay olmadığını, bu maddelerin dönüşümü ve bunları yararlı hale getirecek tek gücün sa'y u amel olduğunu ifade eder (Münif Efendi 1883, 16). Doğada hazır olan birçok nebatat ve hayvanların var olduğunu nebatatları ziraat haline getirmek ve mahsulü elde etmek için sa'y u amel etmek gerektiğini belirtir. Hayvanların yakalanması için sa'y u gayret içerisinde olunması gerektiğini ve yer altında bulunan madenlerin birçok çalışma ve gayretle çıkarılacağını ifade eder. İnsanoğlunun doğada var olan maddeleri sa'y u amel ederek onlardan fazla yarar sağlayacak hale getirilmesini ister (Münif Efendi 1883, 16-17).

Münif Paşa, çalışmanın maddi ve akli olmak üzere iki türlü olduğunu, birincisinin çift sürmek, yük kaldırmak ve bez dokumak gibi işler olduğunu, ikincisinin ise eğitim sürecinden sonra elde edilen ve akıl kuvvetiyle meydana gelen eylemler olduğunu ifade eder. Akli kuvvet ile insanın maddi kuvvetini iyi yöneterek verimli kullanılmasını sağladığını belirtir. İnsanoğlunun akli kuvvetini kullanarak birçok alet ve edevatı icat ettiğini, bunların birçoğunun sanayi sektöründe kullanılarak daha da geliştirildiklerini belirtir. İcat edilen bir aletin bir sonraki nesil tarafından geliştirilerek daha yararlı hale getirildiğini ve farklı kullanımlarının icat edildiğini aktarır. Ulaşım sektöründeki icadın ilk örneklerinin adi ve gereksiz gibi göründügünü ama yeni neslin akli kuvvetle sa'y etmesi sonucu bunların geliştirildiğini dile getirir (Münif Efendi 1883, 17-18). Servetin elde edilmesinde ilim ve hünerin önemli bir katkısı olduğunu söyler. Servetin maddi kuvvetin sonucu elde edildiği görülmesine karşın ilim ve marifet kuvvetine de muhtaç olduğunu belirtir. İnsanoğlunun bilgisi ne kadar fazlaysa dünyadaki varlıklar üzerindeki nüfuz ve iktidarının o nispette olacağını söyler (Münif Efendi 1883, 18).

Münif Paşa, ülkede ziraat ve zanaatın terakki ve gelişmesi için ülkenin sa’y u amelini akli kuvvetiyle desteklemesinin ve bilgi birikimini artırmasının gerektiğini söyler. Bir ülke zanaatkarının bilgisi ne kadar fazla ise mesleğinde o derece başarılı olacağını belirtir. Bir zanaatkarın bilgi seviyesinin yüksek olmasıyla sanayideki alet ve edevatları ve işleyiş tarzını daha çabuk anlayabileceğini ayrıca aletleri geliştirmek için sa'y u amel edeceklerini ifade eder. Malumat sahibi ustaların alet ve edevatların bozulduklarında bunları kolay bir şekilde tamir ettiklerini ve kimseye muhtaç olmadan tadilatı gerçekleştirdiklerini belirtir. Bu gibi mahir ustalar sayesinde zanaatın terakki ettiğini, bu doğrultuda birçok servetin birikmesine hizmet ettiklerini söyler. Cahil ustaların ise alet ve makinaların bozulduklarında bu aletleri hırdavat olarak gördüklerini, yeni aletlerin keşiflerine sıcak bakmadıklarını belirtir. Bu gibi durumlarda ise ülkede terakkinin duracağını ve refahın görülmeyeceğini ifade eder (Münif Efendi 1883, 18-19). 
Münif Paşa, çalışmada akli kuvvetin ve bilginin artırılmasının önemli olduğunu ve bunlardan fazla faydalanmak için iş bölümünün olması gerektiğini ifade eder. İş bölümün toplumun gelişmesiyle ortaya çıtığını her insanın ihtiyaç olduğu üretimini karşılamasının imkânsız olduğunu, karşılarsa bile bundan yüksek verimin elde edilemeyeceğini bu doğrultuda cemiyetlerde iş bölümünün ortaya çıtığını ifade eder. Bir kişinin bir sanatta uzmanlaşmasıyla bundan hem kendisinin hem de toplumun büyük faydalar elde edeceğini üretimin daha artacağını ifade eder. Cemiyetlerde iş bölümünün ortaya çıkmasıyla çeşitli zanaatlarla iştigal edenlerin iş bölümü yaparak üretimi gerçekleştirdiğini ve modern sanayinin bundan doğduğunu söyler (Münif Efendi 1883, 19-20).

Münif Paşa, hıref ve sanayi geliştikçe her zanaatın şubelere bölündüğünü belirtir, örnek olarak da ağaç sektörünü verir. Bu sektörde önceleri sadece dülgerci olmasına karşın zamanla marangozcu, doğramacı, çiçekçi ve diğer sanatların ortaya çıktığını söyler. Zanaatlar çoğaldıkça üretimin daha hızlı olup fazlalaştı̆̆ını ifade eder. İş bölümün sanayide de gerçekleştiğini, bundan dolayı üretimin de fazlalaştığını belirtir. Bir toplu iğnenin üretiminde 18 çeşit imal aşamasından geçtiğini, bunların yapılmasında uzmanlaşıldığını ve üretimin fazlalaştığını ifade eder. Toplumun şimdiki ilerlemişliğine nazaran bir kişinin zanaatın üretim aşamalarını tek başına icra edemeyeceğini belirten MünifPaşa, iş bölümünün sanayide üretimi kolaylaştırıp ve hızlandırdığını söyler. Bu nedenle sa'y u gayrette iş bölümüne dikkat edilmesi gerektiğini ama bunun işçinin ruh ve sağlığını bozacak duruma getirildiği zaman işçinin haklarının korunması gerektiğini ifade eder. (Münif Efendi 1883, 20-21). Sa'y u amel etmenin yanında tasarrufun da önemli olduğunu dile getirir. İnsanoğlunun refah ve saadetini yaşarken geleceğini de düşünmesini ve bu doğrultuda kazandığı paranın bir kısmını tasarruf etmesi gerektiğini ifade eder. İnsanoğlu kazancıyla günün ihtiyaçlarını giderirken geleceğini de düşünmesini ister (Münif Efendi 1883, 21).

II. Abdülhamit döneminin önemli düşünce dergilerinden biri olan Güneş dergisinde Mustafa Azmi tarafindan yazılan "Sa'y u Amel" başlıklı makalede çalışmanın önemi vurgulanmıştır. M. Azmi, sa'y u amelin esirliğin alameti değil özgürlüğün bir nişanesi ve insanoğlunun servet kaynağı olduğunu vurgular. İşsiz kişileri faydasız otlara benzetir. Sa’y u amelin akli başarının anahtarı olduğunu ve sa'y u amelin beden ve akıl kuvvetinin artırılmasını ve kuvvetlenmesini sağladığını söyler. Çalışmanın hayatın şartı olduğunu, bir kuşun uçmak bir balığın yüzmek için yaratıldığı gibi insanın da ancak çalışmak için yaratıldığını belirtir (M. Azmi 1884, 10).

Azmi'ye göre sa'y akıl kuvvetinin jimnastiğidir. Süreklilik, eli yatkınlık, ikdam, kalp rahatllğı, sıhhat, huzur ve sağlığın hep sa'y ü gayretin sonucu elde edilen faydalardır. Sa'y u gayret idarenin, ailenin ve servetin temel kaynağıdır (M. Azmi, 1884, 11). M. Azmi, sa’y u gayretin bir toplumda görülmesi ve yaygınlaşmasıyla o toplumun kalkınmış ve refah içerisinde olacağını ve sa'y u amel içerisinde olan toplumların zenginleşeceğini belirtir. Sa'y u amelde gevşeklik gösterildiğinde refahında eksileceğini ve üretimin durup memleketin fakirleşeceğini bildirir. Çalışmayan toplumların zamanla yok olacaklarını belirtir (M. Azmi 1884, 11)

M. Azmi, önceleri sa'y sonucu kalkınan ve refaha ulaşan bir toplumun zamanla gösterilen gayretsizlik nedeniyle harap olduğunu ifade eder. Sa’y içerisinde olanlardan katil ve serserinin az çıktığı, ama tembellerin ise sürekli zararlı teşebbüsler içerinde olduklarını belirtir. İnsan hayatını sadece sa'y ile sürdürebileceğini, çalışmanın insan fitratının bir gerekliliği olduğunu ve çalışmanın Allah'ın emirlerinden biri olduğunu söyler (M. Azmi 1884 11). Çalışmanın önemini vurgulamak için Kuran'dan ayet örneklerini verir. "Dünyan için ebediyyen yaşayacak imişsin gibi çalı̧̧", "İnsan için semere-i sa'ydan başka bir şey yoktur", "Kasib Allah'in mahbubudur", "Allah'a ittika ile çalışanlara Allah hesabsız verir" (M. Azmi 1884, 11-12). Sonra, çalışmayı teşvik eden atasözlerinden örnekler verir. "Meramın elinden bir şey kurtulmaz", "Çiğnenmeden yutulmaz", "Kime lazım ise ekmek ona lazım ekmek" (M. Azmi 1884, 12).

M. Azmi, sa'y içerisinde olmayan kişilerin hayvanlardan aşağ 1 bir mertebede olduğunu ve sa'y içerisinde olan kişilerin ise toplumun efendisi olduğunu belirtir. İşsizliğin tüm sorunların 
kaynağı olduğunu ifade eder. İşsizlerin daima fenalık içerisinde olduklarını ve topluma zararlı olan her eylem içerisinde bulunduklarını aktarır. Bütün bu olumsuzluklardan çıkmanın ve fenalıkları düzeltmenin tek çaresinin sa'y ile bir işle meşgul olmak olduğunu bildirir. Sa'yın insanı her türlü sıkıntıdan muhafaza ettiğini, her zaman mesut ettiğini buna karşın çalışmamanın ise bedbaht bir duruma düşürdüğünü belirtir (M. Azmi 1884, 12).

M. Azmi, sa’yın, insanın hayatını sürdürebilmesi için önemli bir faktör olduğunu bu doğrultuda insan yaşamak arzusundaysa çalışması gerektiğini ve refah içerisinde olan kişilerin bunu çalışmaya borçlu olduklarını belirtir. İnsanoğlunun tüm ihtiyaçlarını tek başına elde edemeyeceğini, diğer insanların da sa'y sonucu elde ettiği üretime borçlu olduğunu ifade eder. Ancak sadece başkalarına muhtaç olacak bir şekilde hayatını sürdürenlerin ise topluma hiçbir faydalarının dokunamayacağını aktarır. Toplumda çalışmayanların niçin çalışmıyorsun sorusuna çalışacak araçlara sahip olmadıklarını belirtenlere M. Azmi, "Hiçbir serveti mutasarrıf evvela ketm-i ademden beraber getirmemiştir. Dünyada mal ıtlak olunur ne var ise ikdam ile toplanır, sa'y ile vücuda gelir. Bu halden dolayı müzayakaya semere-i atalet, zarurete mahsul-i safahat demek revadır" der. Dünyada çalışmaksızın insan olarak yaşamanın mümkün olmadığını, yaşamak istemeyenlerin sa'y u amel etmesine gerek olmadığını belirtir (M. Azmi 1884, 12-13).

M. Azmi, "İlm-i Servet” başlıklı yazı dizisinde çalışmanın önemini anlatmaya devam eder. M. Azmi, servetin elde edilmesi için üç önemli faktörün olması gerektiğini belirtir, bunlardan birincisi arz, ikincisi sa'y ve üçüncüsünün sermaye olduğunu ifade eder. Servetin elde edilmesinde çalışmanın öneminden bahseder, servetin elde edilmesi ve zenginliğin oluşması için sa'y u amel etmek gerektiğini vurgular. İnsanoğlunun ihtiyaçlarını karşılamayacak şekilde çalışmadan dururlarsa açlıktan telef olacağını belirtir, insanların gereksinimlerini karşılaması için sa'y u gayret içerisinde olmasını ister (M. Azmi 1884, 128). Bir toplumu zengin eden şeyin altın ve gümüşün olmadığını asıl nedenin çalışmanın ve işgüzarlığın olduğunu ifade eder. Amerika'nın zengin ve refah içerisinde olduğunu ama eskiden yerlilerin tembel olduklarından sefalet içerisinde olduğunu söyler (M. Azmi 1884, 130). Sermayenin elde edilmesinde sa'yın önemli olduğunu belirten M. Azmi, sa'ysız sermayenin hiç olduğunu servetin oluşmasında sa'yın önemli olduğunu söyler. Sermaye ile sa'yın birleşmesiyle o ülkede medeniyetin ve refahın görüldüğünü belirtir (M. Azmi 1884, 160).

M. Azmi, sa'ydan fazla verim elde edebilmek için belirli noktalara dikkat edilmesi gerektiğini, sa'yı mümkün olduğu kadar verimli kılmak için vaktinde çalışmak, uygun koşullarda ve meslekte çalışmak ve husn-i surette çalışmak gerektiğini söyler (M. Azmi 1884, 161-163). Servetin elde edilmesinde sa'yın eğitimle ve iş bölümüyle daha da verimli hale getireceğini belirtir. İnsanoğlu sa'yı iki şekilde kullandığını, bunlardan ilkinin yük kaldırmak ve bez dokumak gibi maddi sa'y, diğerinin ise ilim ve fünunu geliştirmek gibi akli sa'y olduğunu açıklar. Beyin gücünün bilgi birikimin gelişmesiyle icra edildiğini ve bu doğrultuda eğitimin önemli olduğunu söyler. Çalışmayı eğitimle verimli hale getirmek gerektiğini, akli kuvvetin geliştirilmesiyle maddi kuvvetin daha etkin kullanılabileceğini, bu doğrultuda ilerlemenin gerçekleşebileceğini ifade eder. Servetin üretiminde insanoğlunun akli kuvvetini geliştirerek icat ettiği yeni aletler sonucu daha hızlı, rahat ve verimli bir şekilde oluştuğunu ve eski neslin geliştirdiği alet ve edevatları yeni neslin onları kullanarak daha da geliştirmelerine imkân sağladığını belirtir. Medeniyette var olan eserlerin eskiden beri yapılan sa'y u gayretin sonucu olduğunu, ilim ve maarifin gelişmesinin servetin üretimindeki ehemmiyetinin olduğunu, servetin sa'y u amel sonucu elde edildiğini, üretimde lazım olacak maddi kuvvet eşdeğerinde akli kuvvete de ihtiyaç duyulduğunu belirtir (M. Azmi 1884, 163-164).

M. Azmi, insanoğlunun sa’y amellerini icra ederken tüm ihtiyaçlarını aynı anda karşılamasını imkânsız olması nedeniyle iş bölümü ve uzmanlaşmanın ortaya çıktığını ve sa'y u amellerin iş bölümü nispetinde kullanılmasılyla yüksek verim elde edildiğini söyler. Birkaç amele bir işe koyuldukları zaman bunların her biri işin birazını gördüklerini diğerleri de arta kalanları icra ettiklerini, bu doğrultuda işin belli bölümlerini aralarında taksim ederek birtakım mesleklerin ortaya çıktığını belirtir (M. Azmi 1884, 219-220). İş bölümünün olmasıyla 
makinelerin icat edildiğini bu nedenle sa'y u amelden daha fazla yarar elde edileceğini söyler. İş bölümü sayesinde sanatlarında uzmanlaşan kişilerin kaliteli ve kolayca üretimde bulunacaklarını ve insanların sa'y u amellerinin veriminin yüksek olacağını ifade eder. Adam Smith'in iş bölümü sayesinde sa'yın kolay bir şekilde icra edilerek fazla verim elde edileceğini ve insanların bir işle olan iştigallerinin fazlalığıyla o işin daha hızlı yapabilme yetilerinin gelişeceğini ve işi kolay yapacak aletleri icat etme olanakların fazla olduğunu belirttiğini vurgular. İnsanoğlunun tüm meslekleri bilmesinin imkânsız olduğundan iş bölümün mutlak anlamda gerekli olduğunu ve bu yöntemle sa'y u amelin verimli ve çabuk gerçekleşeceğini belirtir (M. Azmi 1884, 221-222). M. Azmi, sa'y u amel sonucu elde edilen kazancın harcanmasına değinir, İnsanoğlunun servet elde edebilmesi için çalışma sonucu ele geçen kazancın hepsinin harcamayıp bir kısmını tasarruf edilmesini ister (M. Azmi 1884, 326).

$\mathrm{Ne}$ iş olursa olsun sa'y ve gayret etmeninin önemine binaen dergiye gayret ismini veren Gayret dergisi edebiyat dergisi olmasına karşın çalışmanın önemine değinmiştir. İlk sayıdaki giriş yazısından sonra yayımlanan ikinci yazı sa'y üzerinedir. Kemal Bey tarafından yazılan "Sa'y" adlı makalede insanoğlunun zorunlu olan ve olmayan tüm ihtiyaçlarını çalışma sonucu elde edildiği ve tüm üretimin çalışma sonucu gerçekleştiği ifade edilmiştir. Kemal Bey, bir toplumun kalkınması ve halkın refah içerisinde olmasının tek şartının çalışma olduğunu ve çalışkan milletlerin ticaret ve sanayide büyük başarılar göstereceğini söyler. Bir ülkede sermayeyi artırmanın ve üretimi gerçekleştirmenin tek şartının çalışmak olduğunu ifade eder. Üç günlük geçici dünya için sa'y u gayret ederek çalışmanın gereksiz olduğunu söyleyenleri eleştirir. İnsanoğlunun bu dünyada idamesini sürdürmesini ve refah içerisinde yaşaması için sa'y u gayret etmesi gerektiğini ifade eder. İnsanoğlunun bu dünyaya çıplak bir şekilde gelmesine karşın sa'y u gayret ederek zor olan şartları kolaylaştırdığını, vahşi yaşamı medeni bir toplumda dönüştürdüğünü belirtir ve sa’y u gayretten daha güçlü bir kuvvetin olmadığını söyler. İnsanoğlunun sa'y u gayret elde ettiği medeniyet seviyesine kanaat ederek betalet içerisinde yaşamaması gerektiğini belirtir, sa'y u ikdam ederek bunu daha da geliştirmesini ister. İnsanoğlunun mesleğinde en iyisini üretmek için çaba içerisinde olmasını ve ilminden toplumun istifade etmesi için ilmini daha da geliştirmesinde sa'y u ikdam etmesini arzular (Kemal Bey 1886, 2).

Ülkede halkın bilgi seviyesini artırmak amacıyla eğitici ve öğretici yazıların görüldüğü Maarif' de Ahmed Fuat tarafından yazılan "Sa'y u Gayret" başlıklı makalede çalışmanın önemi anlatılmıştır. A. Fuat, sa'y u gayret insanoğlunun en önemli birinci vazifesi olduğunu, çünkü Allah'ın insanlara çalışmanın önemli bir vecibe olduğunu bildirdiğini belirtir. Sa'y u gayreti icra edenlerin bunun mükafatını elde edeceklerini belirtir. Eğitimin insanoğlunun ruhu olduğunu, bunun ise sa'y u gayretle çoğaldığını ve çalışma ruhunun uyandığı yerde kalkınmanın gerçekleşeceğini ifade eder. Sa'y u gayret içerisinde olanların servet sahibi olacaklarını ve sa'y u gayretin insanı mükemmelleştireceğini bildirir. Sa'y u gayretle müşerref olanların her türlü mevki ile mümtaz olacağını ve sa'y u gayretin her türlü engeli aşarak onları rahata ulaştıracağını belirtir. İlim ve marifetin medeniyeti yolunda kalkınmak için bir makine olarak adlandırılsa bile sa'y u gayretin onun buharı ve enerjisi olduğunu belirtir. Dünyada tüm varlıkların bir vazife ile mükellef olduğunu ve hayvanların eşya taşıma vazifesiyle yükümlü olduğu gibi insanların da sa'y u gayretle mükellef olduğunu ifade eder. Dünyada mevcut olan tüm eserlerin sa'y u gayret sonucu olduğunu ve her şeyin çalışmakla hasıl olduğunu belirtir. İnsanların ulaşmak istedikleri servete ve refaha hep çalışma sayesinde ulaştıklarını ve insanların tüm ihtiyaçlarını temini için çalışmaktan başka vazifeleri olmadığını söyler (A. Fuat 1891, 131-132).

A. Fuat, önceleri bir bölgeden diğer bölgeye girmek için rüzgârlara muhtaç olunduğunu, fakat sa'y u gayretin sonucu insanoğlunu bu bağımlılıktan kurtardığını, su buharıyla ve elektrikle çalışan birtakım makinaların vücuda getirerek önceleri rüzgârların sevkiyle giden gemilerin şimdi kendi kendine hareket ettiklerini ifade eder. Bu sayede insanların dünyada birbirleriyle olan irtibatların yaygınlaşmasıyla ticaretin ilerlediğini ve bu doğrultuda servetlerin çoğaldığını belirtir (A. Fuat 1891, 132). Sa'y u gayretin faydasının sadece bununla kalmadı̆̆ını, karada da uzun mesafeleri kısalaştıran şimendiferlerin icat edilerek seyahati kolaylaştırdığını belirtir. 
Sa'y u gayretle saatler icat ederek insanların vakitlerini doğru tespit edebilmelerini sağladığını ve birtakım kitapların vücuda getirerek ulum ve fünunun gelişmesini sağladığını söyler. Sa'y u gayret sayesinde dünyanın bir ucundan diğer ucuna beş dakikada iletişimin kurulduğunu ve telgraflarla haberleşmenin kolaylaştığını ifade eder (A. Fuat 1891, 132).

Maarif' in 58 ve 59. sayılarında H. Sabri tarafından yazılan “Sa'y u Guşiş” başlıklı makalede çalışmanın hem bu dünyada hem de ahirette insanın kurtuluş rehberi olduğu vurgulanmıştır. Sa'yın ilerleme ve terakki yolunu açtığ ifade edilmiştir. İnsanoğlunun hangi mesleki icra ederse etsin sa'y ve ikdam gösterirse mesleğinde o nispette ilerleyeceği belirtilmiştir. İnsanoğlunun gelişmesi ve kalkınmasının ancak sa'y u gayret ettiği sürece elde edebileceği ifade edilmiştir. H. Sabri, çalışmanın kalkınmanın yolunu açtığını, sa'yın refaha ve gelişmeye sevk eden bir yol olduğunu ve bu yolda durmadan çalışarak devam edilmesi gerektiğini vurgular. Sa'y u gayretin kısa süreli değil sürekli ve devamlı bir şekilde olmasını ister. Bir meslekten ikdam edilmeden gösterilen çalışmadan faydanın elde edilemediğini ve eğer çalışmadan bir fayda elde etmek arzusunda ise bunun ikdam ile güçlendirilmesi gerektiğini belirtir (H. Sabri 1892/a, 83).

H. Sabri eski ve çağdaş dönemdeki tüm meşhur adamların göstermiş oldukları başarının arkasındaki asıl gücün sa’y u ikdam olduğunu söyler. Görülen maddi gelişmelerin ve icat edilen tüm teknolojisinin vücuda gelmesinin sa'y u gayret sonucu olduğunu ve modern toplumun bu teknolojiden büyük yarar elde ettiğini belirtir (H. Sabri 1892/a, 83-84). Dünyada üretilen ve icat edilen her şeyin çalışmakla ilişkili olduğunu, bunların üretilmesinin ikdamla çalışmanın semeresi olduğunu, bu nedenle insanoğlunun hayatın her anında çalışmayı sürdürmesini ister (H. Sabri, 1892/a, 84).

Bir sonraki sayıda H. Sabri çalışmadan hiçbir şeyin meydana gelemeyeceğini bir daha vurgular. Yeni bir teknolojinin icat edilmesi için senelerce sa'y u ikdam edildiğini ve bundan istifadenin birçok zorluk sonucu elde edildiğini belirtir. Tembel bir şahsın hiçbir zaman bir şey meydana getiremeyeceğini ve üretimin ancak sa’y u amel sonucu elde edileceğini söyler. Sa'y u amelin faydaları hakkında geçmişten bugüne birçok bilim adamın sözleri olduğu gibi birçok hadisi şerifte de çalışmayı öven misallerin olduğunu ifade eder (H. Sabri 1892/b, 98).

Selanik’te yayımlanan önemli bir fakir gazetesi olan Mütalaa ülkede halkta görülen tembelliği eleştiren yazılar yayımlamıştır. "Sa'y u Gayret" başlıklı makalede Ahmed Remzi sa'y u gayretin önemini dilenciler örneğiyle dile getirmiştir. A. Remzi, ülkedeki dilencilere nasihat olarak Paris'teki bir anısını anlatmaya başlar. Paris'te Antuan adlı bir dilencinin para için sürekli dilendiğini belirtikten sonra bir gün dilenmeye devam ederken bir şahsın dilenciye seslenerek sağlam ve işe yarar birine benziyorsunuz ama kendinize yakışmayacak ve zelil bir zanaat icra ediyor gibi sözler söyledikten sonra size vereceğim nasihati tatbik ederseniz sizi bu meslekten kurtaracak 10 bin liralık bir gelire sahip bir kişi olabilirsiniz dediğini, ama bu sözler üzerine dilenci beraber güldüklerini, ama ihtiyarın tavrını bozmayarak nasihatlerimi dinlerseniz bu serveti elde edileceğini söyledikten sonra kendi hayat hikayesini anlatmaya başladığını, zamanında kendisinin fakir olup bir küfe tedarik ederek köylerde paçavralar topladığını, bunları Paris’te kağıt fabrikasına sattığını, bir süre sonra sermayenin çoğaldı ̆̆ını, küçük ticaretini geliştirerek küçük bir araba satın aldığını, paçavraları dahi para karşılığında almaya başladığını, on senenin sonunda 30 bin frank sermayeye sahip olduğunu, bir kağıt fabrikasının kızıyla izdivaç ederek şirketine ortak olduğunu, sa'y u gayret ederek çalışmaya devam ettiğini, Paris’te iki tane kağıt fabrikasına sahip olduğunu, oğluna sa'y u gayretin önemini anlattığını, öğrettiğini, tüm işlerini ona terk ettiğini, hayatını yaşadığını, hayatında sa'y u gayret ederek birkaç yüz nüfusa iş verir duruma geldiğini ifade ederek konuşmasını bitirdiğini ve dilenci Antuan'ın bu sözlerden sonra derin derin düşünmeye başladığını aktarır. Bu olaydan yirmi sene sonra Brüksel'e işi icabı bulunduğunda birkaç keten almak için bir matbaaya girdiğinde aşağı yukarı gezen şık kıyafetli birinin yirmi otuz kişiye emirler verdiğine şahit olduğunu, bu adamla sonra yüz yüz geldiklerinde birbirini tanıyan iki kişi gibi birbirlerinin yüzüne baktıklarını ve Antuan'ın beni tanımadınız mı? Bundan yirmi sene önce Paris'te bulunmadınız mı? demesiyle Antuan siz misiniz? diye sorduğunu Antuan'ın evet 
benim diye cevap verdiğini, ihtiyarın hakkı varmış sa'y u gayret ederek sekiz bin liraya malik olduğunu ifade ettiğini belirtir (A. Remzi 1896, 5-6).

\section{Sonuç}

Osmanlı devleti 19. yüzyılın ilk yarısında ekonomisini geliştirmek ve ülkeyi modernleştirmek için birçok girişime girmesine karşın bunda başarılı olamayınca yeni arayışlar içerisine girmiştir. Batılı devletlerin iktisadi olarak gelişmişliğinin farkında olan teşebbüs-i şahsi fikrini savunan Osmanlı aydınları bunun nedenlerini araştırmışlar ve bu doğrultuda Batılı devletlerin iktisadi olarak gelişmesinin en önemli gücün halkın sanayi ve ticaret gibi özel girişim getiren sektörlerde sa'y u amel etmesinde görmüşlerdir. Batılı halkların maişetlerini karşılamak için devlet kapısında memur olmak düşüncesinden ziyade özel sektörlerde girişimlerde bulunmalarının bir rekabet ortamı yaratarak hem kendilerinin refah seviyesini artmasını hem de devletlerin iktisaden kalkınmasını sağladığını gözlemlemiş̧lerdir. Aydınlar Batılı halkların maddi sa'yın yanında akli sa'ya önem verdiklerini akli sa'yı kuvvetlendirmek için her türlü mesleki eğitim kurumlarını oluşturduğu ve kendi mesleklerinde her zaman daha iyi olmak için çabaladıklarını belirtmişlerdir.

Aydınlar, Osmanlı devletinin Batılı devletler gibi kalkınamamasının en önemli nedeni olarak halkın özel sektör faaliyetlerinde sa'y etmeyip devlet kapısında memur olarak maişetlerini karşılamasında görür. Halkın en önemli gayesinin devlet kapısında memur olma arzusunun ülkede özel girişim faaliyetlerin azalmasına neden olduğunu belirtir. Zanaat ve ticaret gibi sektörlerde faaliyet içerisinde olanlara hakir görüldüğünü ifade eder. Bu sorunu ortadan kaldırmak amacıyla halkın özel sektör faaliyetlerinde sa'y u amel etmelerinin önemini dönemin basınında dillendirmişlerdir. Halkın en önemli güç kaynağı olan sa'y u amelin farkında olmalarını sağlamak amacıyla çalışmayı öven tembelliği yeren yazılarla halka çalışma psikolojisi aşılanmaya çalışılmıştır.

1860 senesinde ülkede gazetelerin yaygınlaşmasıyla ülkede bir kamuoyu oluşmuş, basın halkı yönlendirme ve bilgilendirme rolünü oynamaya başlamıştır. Osmanlı devletinde basının halkı yönlendirme ve bilgilendirme rolünün yanında baskın olarak işlevi olan diğer bir rolü ise eğitimdir. Dönemin gazetelerinde yazılar yazan aydınlar, halkın bilgi seviyesini artırmak, onları eğitmek amacıyla da yayın politikası gütmüş ve birçok sektörde eğitici yazılar yayımlamışlardır. Gazeteler vasıtasıyla Osmanlı halkını iktisadi olarak da şuurlandırmaya çalışmış, bu doğrultuda eğitici ve öğretici yayınlar yapmışlardır. Halkın refah seviyesinin artması ve devletin kalkınması için sa'y u amel etmesi istenmiş, bu şuurun halkta oluşması için birçok yazı kaleme almışlardır.

Teşebbüs-i şahsi fikrini savunan Osmanlı aydınları dönemin gazetelerinde sa’y u amel vurgusunu veren yazılarda halkın çalışma teşvikinin az olduğu, zanaat ve ticaret gibi mesleklerin hor görüldüğü, kazanç peşinde koşmada kanaatkâr tavır takındığı, çalışmada akli sa'ya önem verilmediği gibi sorunları dillendirmişlerdir. Bu sorunları ortadan kaldırmak amacıyla zanaat ve ticaret gibi meslekleri öven, çalışma hırsını artıran ve akli sa' yın önemini dile getiren yazılar kaleme almışlardır. Halkın geçimini sağlamakla mükellef olduğunu bunun en iyi şekilde ise çalışma ile elde edeceğini ve tüm varlıkların bir amacı olduğu gibi insanoğlunun ana amacının sa'y u amel etmesi olduğunu belirtmişlerdir. Kalkınmanın ve zenginleşmenin tek şartının çalışma olduğu ve paranın bir aracı rolünü oynadığı servetin asıl kaynağının sa'y olduğunu vurgulamışlardır.

Aydınlar, çalışmanın maddi ve akli sa'y olarak ikiye ayrıldığını, bu iki kuvvetin aynı anda işlevini gerçekleştirilmesiyle insanoğlunun çalışmadan daha büyük faydalar elde edeceğini ifade etmişlerdir. Maddi sa'yı akli sa'y ile kuvvetlendirmek gerektiğini ve akli sa'yı ise zenginleştirmek için çaba gösterilmesini istemişlerdir. Bugünkü modern teknolojinin akli sa'yın sonucu ortaya çıktığını ifade etmişler, bu doğrultuda akli sa'yın işlevinin artırılmasıyla bilinmeyen birçok teknolojinin ortaya çıkabileceğini belirtmişlerdir. Ülkede zanaat ve ticaret erbabının akli sa'ya önem vermediğini dile getiren aydınlar, bu kuvvetin artırılması için eğitim kurumlarının artırılmasını talep etmiş, meslek ustaların kendilerini geliştirmemelerini tenkit etmişlerdir. Halkın maişetlerini karşılaması için maddi ve akli sa'y içerisinde olmalarını istemeleri yanında onların 
sermaye sahibi olmaları için harcamalarında itidalli davranmaları gerektiğini ifade etmişlerdir. Halkta tasarruf etme duygusunu geliştirmek için birçok yazı kaleme alan aydınlar servet sahibi olanların gereksiz harcamalar içerisinde olduğunu belirtmişler, mevcut sermayelerini yatırım gerektiren işlerde kullanmamalarını tenkit etmişlerdir. Aydınlar ülkede mirasa konan kişilerin bu serveti israf ederek harcamalarını, bu gibi kişilerin toplumda saygı görmelerini ve bunlara imrenilmesini eleştirmişlerdir. En güzel harcamanın insanın alın teriyle kazandığı kazancın harcaması olarak açıklamışlardır.

\section{Kaynakça}

A. Fuat (18 Rebiülevvel 1309/22 Ekim 1891), “Sa’y u Gayret”, Maarif, Sayı:9, 131-133.

Ali Suavi (25 Şaban 1283/1 Ocak 1867), “Mukaddime”, Muhbir, Sayı:1, 1.

A. Remzi (20 Ağustos 1312/1 Eylül 1896), “Sa’y u Gayret”, Mütalaa, Say1:5, 5-6.

E. Tevfik (Zilhicce 1289/Şubat 1873), “Tarik-i Servet Mukaddime”, Cüzdan, Sayı:1, 22.

E. Pertev (Şaban 1281/Ocak 1865), "Medh-i Sa’y ve Zemm-i Betalet Hakkında Meşahir-i Ulema-yı İslamiyeden Kemal Paşazadenin Arabi Risalesinin Tercümesidir", Mecmua- $i$ Fünun, Say1:32, 281-289.

H. Sabri (25 Muharrem 1310/19 Ağustos 1892/a), "Sa’y u Guşiş”, Maarif, Say1:58, 83-84.

H. Sabri (1 Safer 1310/25 Ağustos 1892/b), “Sa’y u Guşiş”, Maarif, Say1:59, 98.

Kemal Bey (3 Kanunisani 1301/15 Ocak 1886), "Başlıksız Yazı (Sa’y Hakkında)”, Gayret, Say1:1, 2.

Macid Bey (Cemaziyelahir 1283/Ekim 1866), "Lüzum-1 Sa’y u Amel”, Mecmua-i Fünun, Say1:39, 201-206.

M. Azmi (1301/1884), “Sa’y u Amel”, Güneş, Sayı:1, 10-13.

M. Azmi (1301/1884), “İlm-i Servet”, Güneş, Sayı:3, 125-130.

M. Azmi (1301/1884), “İlm-i Servet”, Güneş, Sayı:4, 159-165.

M. Azmi (1301/1884), “İlm-i Servet”, Güneş, Say1:5, 219-224.

M. Azmi (1301/1884), “İm-i Servet”, Güneş, Sayı:7, 326-330.

M. Nadir (1 Muharrem 1300/12 Kasım 1882), “Gayret-i Ciddiye”, Afak, Sayı:2, 59-63.

Münif Efendi (Rebiülevvel 1300/Ocak 1883), “Tahsil-i Servet”, Mecmua-i Fünun, İkinci Dönem, Say1:1-48, 15-22.

Namık Kemal (Zilhicce 1289/Şubat 1873), “Sa’y”, Cüzdan, Sayı:1, 2-5.

Ohannes Efendi (Safer 1279/Temmuz 1862), “İlm-i Servet-i Milel”, Mecmua-i Fünun, Say1:2, 86-92.

Reşad Bey (Zilhicce 1289/Şubat 1873), "Franklin Tarik-i Servet”, Cüzdan, Sayı:1, 22-28.

R. Tevfik (20 Zilhicce 1299/2 Kasım 1882), “Cümle-i Hikemiye” Afak, Sayı:1, 7-9.

Şerif Efendi (Şaban 1279/Ocak 1863), “Lüzum-1 Sa’y u Amel”, Mecmua-i Fünun, Say1:8, 333-337.

Tayr (3 Safer 1300/14 Aralık 1882) "Çalışma”, Afak, Sayı:4, 118-120.

“Güneş” (1986), Türk Dili ve Edebiyatı Ansiklopedisi, C:3, İstanbul, Dergâh Yayınları, 409. 
“Gayret” (1986), Türk Dili ve Edebiyatı Ansiklopedisi, C:3, İstanbul, Dergâh Yayınları, 293-294.

“Maarif” (1986), Türk Dili ve Edebiyatı Ansiklopedisi, C:6, İstanbul, Dergâh Yayınları, 108.

"Mütalaa" (1986), Türk Dili ve Edebiyatı Ansiklopedisi, C:6, İstanbul, Dergâh Yayınları, 487488.

Berkes, N. (2003), Türkiye'de Çağdaşlaşma, İstanbul, Yapı Kredi Yayınları, 5. Baskı.

Budak, A. (2004), Batılılaşma Sürecinde Çok Yönlü Bir Osmanlı Aydını, İstanbul, Kitabevi, 2004.

Çavdar, N. (2014), "Muhbir Gazetesinin Bir Toplumsal Sorumluluk Projesi: Girit İsyanında Zarar Gören Müslümanlar İçin Yardım Kampanyası", Sultan Abdülaziz ve Dönemi Seтроzуити, C:4, 12-13 Aralık 2013, Ankara, Türk Tarih Kurumu Yayınları, 99-126.

Çavdar, T. (2007), İ Bırakan Gazeteler ve Gazeteciler, Ankara, İmge Yayınevi.

Karpat, K. H. (2005), İslam 'ın Siyasallaşması, İstanbul, Bilgi Üniversite Yayınları, 2. Baskı.

Mardin, Ş. (2002), Yeni Osmanlı Düşüncesinin Doğuşu, İstanbul, İletişim Yayınları, 3. Baskı.

Nalcıoğlu, B. U. (2013), Osmanlı'da Muhalif Basının Doğuşu, İstanbul, Yeditepe Yayınları.

Okay, M. O. (1996), “Güneş”, İslam Ansiklopedisi, C:14, İstanbul, Diyanet Vakfi Yayınları, 296297.

Okay, O. (1988), “Afak”, İslam Ansiklopedisi, C:1, İstanbul, Diyanet Vakf1 Yayınları, 396.

Okay, M. O. (2003), "Maarif”, İslam Ansiklopedisi, C:27, Ankara, Diyanet Vakfi Yayınları, 272273.

Ortayl1, İ. (2000), İmparatorluğun En Uzun Yüzyılı, İstanbul, İletişim Yayınları, 6.Bask1.

Özlük, N. (Ocak-Haziran 2011), “Afak Mecmuası ve Dizini”, Yeni Türk Edebiyatı Araştırmaları Dergisi, Y11:3, Say1:5, 201-208.

Şen, N. (2009), “Tanzimat Devri Periyodikleri ve Dergicilik”, Gazi Türkiyat, Say1:5, 381-393.

Topuz, H. 100 Soruda Türk Basın Tarihi, İstanbul, Çiçek Yayınevi, 1973.

Uçman, A. (Kasım 1999), “Tanzimat’tan Sonra Kültür Hayatımızdaki Değişme ve Yenileşmeler”, Tarih ve Toplum, C:32, S:191, 9-14.

Varlık, B. (1985), “Tanzimat ve Meşrutiyet Dergileri”, Tanzimat'tan Cumhuriyet'e Türkiye Ansiklopedisi, C:1, İstanbul, İletişim Yayınları, 1985, 112-125.

Yazı1, N. (1994), “Tanzimat Dönemi Basını Konusunda Bir Değerlendirme”, Tanzimat'ın 150. Yıldönümü Uluslararası Sempozyumu, 1989, Ankara, Türk Tarih Kurumu Basımevi, 55-84.

Yazıcı, N. (2003), "Maarif Dergisi Penceresinden Osmanlı Başkentinde 1892 Ramazanına Bakış", İstem, Y:1, S:1, 49-60.

Ziyad Ebuzziya (2007), Şinasi, Haz. Hüseyin Çelik, İstanbul, İletişim Yayınları, 2. Baskı. 